\title{
Effect of Thermocycling And E-Glass Fiber Addition on Water Sorption And Color Stability of Thermoplastic Nylon Denture Base Material
}

\author{
Ariyani, ${ }^{1 *}$ Ismet Danial Nasution, ${ }^{1}$ Harry Agusnar ${ }^{2}$ \\ ${ }^{1}$ Department Of Prostodontics, Faculty Of Dentistry, University Of Sumatera Utara \\ ${ }^{2}$ Department Of Chemistry, Faculty Of Mathematics And Natural Sciences, University Of Sumatera Utara
}

\begin{abstract}
Background /purpose : The aim of this in vitro study wasto find out the effect of thermocycling and E-glass fiber addition on water sorption and color stability of nylon thermoplastic denture base material

Materials and methods :Thirty samples of nylon thermoplastic denture base material were divided into 6 groups, consisting of group $1 \%$ and 1,5\% E-glass fiber with and without thermocycling and group without Eglass fiber. Measurement of water sorption value by using analytical balance and color stability measurement by using UV Spectrophotometer. The effect of thermocycling on water sorption and color stability was analyzed with $T$ test and the effect of E-fiber on water sorption and color stability was analyzed with one way ANOVA test. The comparison of effect among group without E-glass fiber, with $1 \%$ and $1,5 \% \mathrm{E}$-glass fiber with and without thermocycling was analyzed with LSD test.
\end{abstract}

Results : There was an effect of thermocycling with 2000 cycle as the simulation of oral cavity condition for 2 years denture usage on water sorption and color stability in group without E-glass fiber and group with addition of $1 \%$ and $1,5 \%$ of E-glass fiber. One way ANOVA test showed that there was an effect of E-glass fiber addition on water sorption and color stability of nylon thermoplastic denture base material with and without thermocycling.

Conclusion : According to this study, thermocycling shows an effect on water sorption and color stability. Eglass fiber addition to denture base material also affects water sorption and color stability as seen from discoloration of denture base material with the addition of $1 \%$ to 1,5\% E-glass fiber in thermocycled group is not visible and acceptable $(\Delta E<3,3)$, while in group without E-glass fiber addition, discoloration is clearly seen visually and unacceptable $(\Delta E>3,3)$.

Keywords: Absorption, Color, E Glass Fiber, Nylon, Thermocycling

\section{Introduction}

A denture base is part of a denture whichteeth are attached, receive functional force, distribute the force and increase the aesthetic especially when the base looks nature. ${ }^{1}$ Classification of the denture base polymers based on ISO 1567is divided into five types, one of the most frequently used is type 1 (heat processing polymers) denture base acrylic resin polymerization heat (RAP) which is processed by compression molding. ${ }^{2-5}$ Acrylic resin material was first discovered by Wright in $1937 .{ }^{6}$ Acrylic resin have some advantages, but the material still has disadvantages, that is metal clasps attached to the acrylic resin base frequently lead to various problems and complaints from patients, for example, excessive pressure on the abutment tooth and aesthetic problems, there are a small number of patients reporting allergic to acrylic resin in specifically against residual monomers of methyl methacrylate contained in the denture base. ${ }^{4,7}$ Thermoplastic nylon material as a base denture processed with injection molding method was developed to overcome the deficiency of acrylic resin materials. ${ }^{4}$

Thermoplastic nylon used as a denture base material in the 1950s. Since it was introduced, interest in this material is increasing. Some of the advantages of thermoplastic nylon base materials are aesthetic due to the translucency of the material and the invisibility of clasp on the abutment tooth; can be made thinner because it has good strength so it is more convenient to use and flexible so it can adapt well to the undercut area, biocompatible, unbreakable, resistant to heat, free from residual monomer, and hypoallergenic. ${ }^{4,6,8-11}$ Kortrakulkij $\mathrm{K}$ (2008) citing the opinion of Matthews and Smith using nylon as a denture base, and the clinical results showed a tendency of nylon to discoloration, staining, large water sorption and increased surface roughness after being used a few weeks. ${ }^{3}$ Those are disadvantage of thermoplastic nylon.

Color stability is a very important clinical characteristics in dental restoration materials and denture base materials. ${ }^{3,12,13}$ Discoloration denture base is caused by two factors: intrinsic and extrinsic. Extrinsic factors 
are the color change caused by sorption of water through the process of absorption and adsorption. Adsorption and absorption can cause staining of the resin due to pigment contained in the oral cavity and causing discoloration of the resin. Water sorption of a material should be kept as low as possible because excess water will affect the color stability of these materials. ${ }^{12,14,15}$

In the denture base polymer, the value of water sorption should be less than or equal to $32 \mathrm{ug} /$ $\mathrm{mm}^{3} \cdot{ }^{16,17}$ Water enters into denture base material through the process of diffusion, water molecules enter into the space between polymer chains due to small size of the water molecule which is less than $0.28 \mathrm{~nm}$, smaller than the distance between polymer chains in a polymer matrix and cause the distance between the chain become more distant, causing the expansion, affecting the strength, stability, physical, mechanicalproperties and color stabilityof the material. ${ }^{16-18}$ High water sorption inthermoplastic nylon denture base material caused by a single linear chain structure which is weaker than thecross-linking chain structure ofthe denture base acrylic resin polymerization heat. ${ }^{3,4,11}$

One of the methods to reduce the water sorption is the addition of E-glass fibers in polymer materials. E-glass fibers in the form of small pieces has the advantage such as more practical and evenlyspread. ${ }^{19}$ Valittu P., et all., (2003) stated that the lowest water sorption among the group added fiber $1 \%, 3 \%$ and $5 \%$ were in the group added fiber $5 \%$, the results showed that the number of glass fibers concentrations were added affect the value of water sorption. ${ }^{16} \mathrm{Al}-$ Vurakarra VR. (2006) states that water sorption is significantly reduced with the addition of glass fibers on the polymethyl methacrylatematerial. ${ }^{18}$ The result of research Ariyani (2013) showed the addition of E-glass fiber $1 \%$ and $1.5 \%$ on a thermoplastic nylon base material may reduce water sorption and improve color stability of these materials. ${ }^{20}$

Other factor affecting the stability of the color is intrinsic factorthat change color due to the aging process of a substance that occurs because of material exposed to the physical and chemical condition due tochanges of temperatureand moisture. ${ }^{12,15}$ The color change that occurs in a material commonly associated with aging. Thermocycling is one of the methods simulation in vitro to evaluate the physical and mechanical properties of the material after the process of aging. ${ }^{15,21}$ Thermocycling also significantly affect the hardness, water sorption, solubility and changes in color of a polymer material. ${ }^{22}$ The changes of colour is considered as an indicator of aging or damage of a material. Nadira A.H (2013) stated that the color changes after thermocycling was highest in thermoplastic nylon material than acrylic resin. This is because the nylon is a hydrophilic material, has a large water sorption thus easy for color changes. ${ }^{23}$ Low water sorption and solubility can reduce the changes of color in material after aging. ${ }^{22}$ The addition of glass fibers in the thermoplastic nylon material is expected to reduce water sorption that occurs due to changes in temperature and humidity during thermocycling procedure.

Based on the above, the researcher felt the need to evaluate the sorption of water and color stability thermoplasticnylon denture base material with and without the addition of E-glass fiber $1 \%$ and $1.5 \%$ as well as with and without thermocycling.

\section{Materials and Methods}

Thirty samples of thermoplastic nylon denture base material were divided into 6 groups, consisting of a group without E-Glass fibers, E-Glass fibers $1 \%$ and $1.5 \%$ with and without thermocycling.Each group consists of 5 specimens. The size of specimens for water sorption and color stability based on the international organization for standardization (ISO) is a cylindrical shape withdiameter of $15 \pm 1 \mathrm{~mm}$, with thickness of $0.5 \pm$ $0.1 \mathrm{~mm} \cdot{ }^{24}$ Specimens were made using thermoplastic nylon 6 (Bioplast)materials by injection molding techniques. Finishing of the specimens were done with water proof sand paper attached to the rotary grinder and water flowing at a speed of $500 \mathrm{rpm}$ for 5 minutes. Proceed with scotch-brite brush attached to the polishing motor with a speed of $500 \mathrm{rpm}$ using coarse pumice until the specimens were shiny.

E-Glass fiber chopped strands of $3 \mathrm{~mm}$ size( KCR 2, Cam Elyaf San A.S.,Kocaeli, Turki) immersed in a silane coupling agent (gamma - methacryloxypropyltrimethoxysilane / MPS) before being added to the thermoplasticnylon material with layer by layertechnique in the cartridge.Fifteen specimens were thermocycling using thermocycling machine (TC 301, 0-999,999 Cycle, Thailand), around 2,000 cycle (simulated use of 2 years), temperature $5^{\circ} \mathrm{C}-55^{\circ} \mathrm{C}$, for 60 seconds. Then the whole specimens were inserted into a desiccator for 24 hours for the purpose of desiccation and prevents contact with the outside humidity. Desiccation process is repeated until the specimens experienced a weight loss does not exceed $0.5 \mathrm{mg}$ in a 24 hour period. Then specimens were inserted into aquabidest and kept in an incubator for 7 days at a temperature of $37 \pm 2^{0} \mathrm{C}$. After 7 days the specimens are removed from the water and cleaned with a dry cloth and left in the open air for 15 seconds. Weigh the sample after the first minutes of being out to get $\mathbf{M}_{2}$. Specimens are reinserted into desiccator until constant weigh and reweigh using the analytical balance to obtain the value of $\mathrm{M}_{3}$. Measurement of the value of water by using the formula:

Water Sorption $=\quad \mathrm{M}_{2}-\mathrm{M}_{3}\left(\mu \mathrm{g} / \mathrm{mm}^{3}\right)$ 
Volume $\left(\mathrm{mm}^{3}\right)$

After the measurement of water sorption, specimens were measured using Spectrophotometer UV Ultra Scan xe d65 (Hunter lab. Scan XE, Germany). T test was conducted to determine the effect of thermocycling against water sorption and color stability, while the One-way ANOVA was conducted to determine the effect of the addition of E-Glass fiber against the sorption of water and color stability.

\section{Effect of Thermocycling to Water Sorption}

\section{Results}

The results showed an average value of water sorption were analyzedwith Univarian test. Mean and standard deviation of the thermoplastic nylondenture base material without E-glass fiber and without thermocycling was $17,421 \pm(1,290) \mu \mathrm{g} / \mathrm{mm}^{3}$, while with thethermocycling was $31,479 \pm(0,947) \mu \mathrm{g} / \mathrm{mm}^{3}$. Mean and standard deviation of the nylon thermoplasticdenture base material with the addition of E-glass fiber $1 \%$ without thermocycling was $14,027 \pm(0,620) \mu \mathrm{g} / \mathrm{mm}^{3}$ while with the thermocycling was $28,308 \pm(1,132)$ $\mu \mathrm{g} / \mathrm{mm}^{3}$. Mean and standard deviation of the nylon thermoplasticdenture base material with the addition of Eglass fiber $1.5 \%$ without thermocycling was $12,218 \pm(0,946) \mu \mathrm{g} / \mathrm{mm}^{3}$ while with the thermocycling was 24,912 $\pm(2,655) \mu \mathrm{g} / \mathrm{mm}^{3}$ (Chart 1).

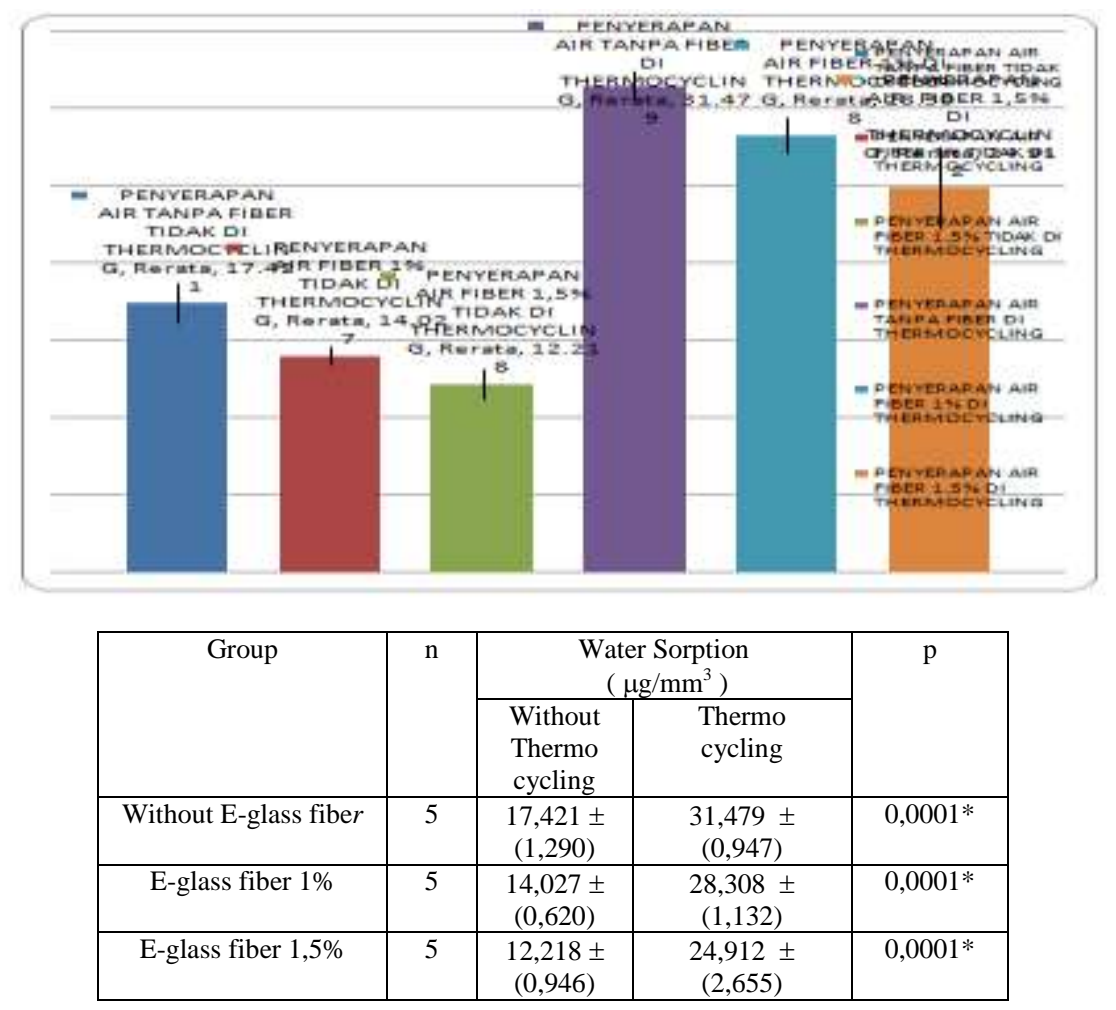

Chart 1. Mean and standard deviation of the water sorption thermoplastic nylon denture base material without and with the addition of E-glass fiber $1 \%$ and $1.5 \%$ without or with thermocycling.

$\mathrm{T}$ test results showed no significant difference value between the groups of water sorption without and with the addition of E-glass fiber $1 \%$ and $1.5 \%$ without or with thermocyclingwere $p=0,0001(p<0,05)$, hence there were thermocycling effect to the water sorption in thermoplastic nylon denture basematerial without and with the addition of E-glass fiber $1 \%$ and $1.5 \%$.(Table 1 ).

Table 1 . The value of of water sorption in thermoplastic nylondenture base material without and with the addition of E-glass fiber $1 \%$ and $1.5 \%$

\section{Effect of Thermocycling to Color Stability}

The results showed an average value of color stability were analyzedwith Univarian test. Mean and standard deviation of the thermoplastic nylondenture base material without E-glass fiber and without thermocycling was $1,418 \pm(0,258)$, while with thethermocycling was 4,238 $\pm(0,683)$. Mean and standard deviation of the nylon thermoplasticdenture base material with the addition of E-glass fiber $1 \%$ without 
thermocycling was $1,015 \pm(0,167)$ while with thethermocycling was $2,605 \pm(0,446)$. Mean and standard deviation of the nylon thermoplasticdenture base material with the addition of E-glass fiber $1.5 \%$ without thermocycling was $0,597 \pm(0,214)$ while with thethermocycling was $1,842 \pm(0,218)$ (Chart 2).

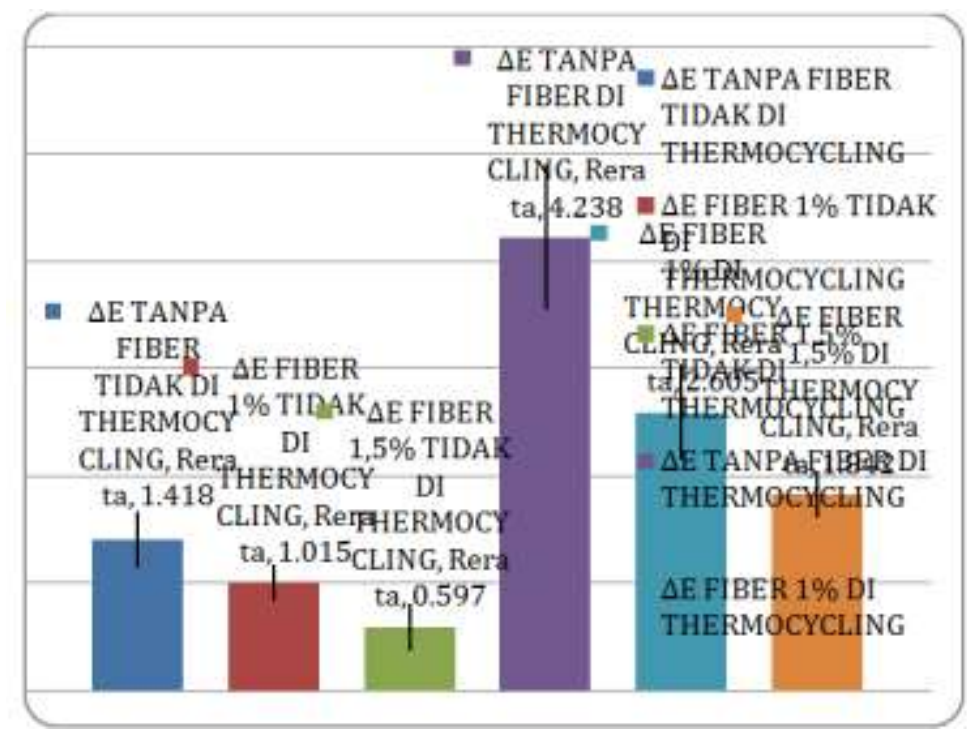

Grafik 2. Chart 1. Mean and standard deviation of the color stability thermoplastic nylon denture base material without and with the addition of E-glass fiber $1 \%$ and $1.5 \%$ without or with thermocycling.

$\mathrm{T}$ test results showed a significant difference value between the groups of color stability without Eglass fiberwas $\mathrm{p}=0,0001(\mathrm{p}<0,05), \mathrm{p}=0,001(\mathrm{p}<0,05)$ on group with the addition of E-glass fiber $1 \%$ andp $=$ $0,0001(\mathrm{p}<0,05)$ on group with the addition of E-glass fiber $1.5 \%$ without conducting thermocycling, hence there are thermocycling effect to color stability of thermoplastic nylon denture base material without and with the addition of E-glass fiber $1 \%$ and $1.5 \%$ (Table 2).

Table 2. The color stability of thermoplastic nylon denture base material without and with the addition of Eglass fiber $1 \%$ and $1.5 \%$

\begin{tabular}{|c|c|c|c|c|}
\hline \multirow[b]{2}{*}{ Group } & \multirow[b]{2}{*}{$\mathrm{n}$} & \multicolumn{2}{|c|}{ Color Stability $(\Delta \mathrm{E})$} & \multirow[b]{2}{*}{$\mathrm{P}$} \\
\hline & & $\begin{array}{l}\text { Without } \\
\text { Thermo } \\
\text { cycling }\end{array}$ & $\begin{array}{l}\text { Thermo } \\
\text { Cycling }\end{array}$ & \\
\hline $\begin{array}{l}\text { Without E- } \\
\text { glass fiber }\end{array}$ & 5 & $\begin{array}{l}1,418 \pm \\
(0,258)\end{array}$ & $\begin{array}{c}4,238 \pm \\
(0,683)\end{array}$ & $0,0001 *$ \\
\hline $\begin{array}{c}\text { E-glass fiber } \\
1 \%\end{array}$ & 5 & $\begin{array}{l}1,015 \pm \\
(0,167)\end{array}$ & $\begin{array}{c}2,605 \pm \\
(0,446)\end{array}$ & $0,001 *$ \\
\hline $\begin{array}{c}\text { E-glass fiber } \\
1,5 \%\end{array}$ & 5 & $\begin{array}{l}0,597 \pm \\
(0,214)\end{array}$ & $\begin{array}{c}1,842 \pm \\
(0,218)\end{array}$ & $0,0001 *$ \\
\hline
\end{tabular}

\section{Effect of addition E-glass fiber to Water Absorption}

ANOVA test results showed the effect of the addition of E-glass fibers in thermoplastic nylon denture base material to the water sorption with value $\mathrm{p}=0.0001(\mathrm{p}<0,05)$. Based on LSD test results show significant difference between the nylon thermoplasticdenture base material without and with the addition of E-glass fiber $1 \%$ with $\mathrm{p}=0,0001(\mathrm{p}<0,05)$ and with additional of E-glass fiber $1.5 \%$ with $\mathrm{p}=0,0001$. Significant differences were also found between thermoplasticnylon denture base material with the addition of E-glass fiber $1 \%$ and $1.5 \%$ with value $\mathrm{p}=0,014(\mathrm{p}<0,05)$ (Table 3$)$

ANOVA test results showed the effect of the addition of E-glass fibers in thermoplastic nylon denture base material to the value of the watersorption with $p=0,0001(\mathrm{p}<0,05)$. Based on LSD test results, it showed a significant difference between the thermoplasticnylondenture base material without and with the addition of $\mathrm{E}$ glass fiber $1 \%$ with $\mathrm{p}=0,014(\mathrm{p}<0,05)$, and with additional of E-glass fiber $1,5 \% \mathrm{p}=0,0001(\mathrm{p}<0,05)$. Significant differences were also found between thermoplasticnylon denture base material with the addition of E-glass fiber $1 \%$ and $1.5 \%$ with value $p=0,010(p<0,05)($ Table 4$)$.

Table 3. Effect of the addition E-glass fiber $1 \%$ and $1.5 \%$ to water sorption of thermoplasticnylon denture base material without thermocycling 


\begin{tabular}{|c|c|c|c|}
\hline \multirow{2}{*}{ Group } & \multicolumn{2}{|c|}{$\begin{array}{c}\text { Water Sorption } \\
\left(\mu \mathrm{g} / \mathrm{mm}^{3}\right)\end{array}$} & \multirow{2}{*}{$\mathrm{p}$} \\
\cline { 2 - 3 } & $\mathrm{n}$ & Mean $\pm(\mathrm{SD})$ & \multirow{2}{*}{$0,0001^{*}$} \\
\hline $\begin{array}{c}\text { Without E-glass } \\
\text { fiber }\end{array}$ & 5 & $17,421 \pm(1,290)$ & \\
\hline E-glass fiber 1\% & 5 & $14,027 \pm(0,620)$ & \multirow{2}{*}{$0,0001^{*}$} \\
\hline E-glass fiber 1,5\% & 5 & $12,218 \pm(0,946)$ & \multirow{2}{*}{$0,0001^{*}$} \\
\hline $\begin{array}{l}\text { The mean the watersorption is different between: } \\
\text {-Without E-glass fiber with E-glass fiber 1\% }\end{array}$ & $0,014^{*}$ \\
\hline
\end{tabular}

Table 4. Effect of the addition E-glass fiber to water sorption of the thermoplastic nylon denture base material with thermocycling

\begin{tabular}{|c|c|c|c|}
\hline Group & \multicolumn{2}{|c|}{$\begin{array}{c}\text { Water Sorption } \\
\left(\mu \mathrm{g} / \mathrm{mm}^{3}\right)\end{array}$} & \multirow{2}{*}{$\mathrm{P}$} \\
\cline { 2 - 3 } & $\mathrm{n}$ & Mean $\pm(\mathrm{SD})$ & \multirow{2}{*}{$0,0001^{*}$} \\
\hline $\begin{array}{c}\text { Without E- } \\
\text { glass fiber }\end{array}$ & 5 & $31,479 \pm(0,947)$ & \\
\hline $\begin{array}{c}\text { E-glass } \\
\text { fiber 1\% }\end{array}$ & 5 & $28,308 \pm(1,132)$ & \\
\hline $\begin{array}{c}\text { E-glass } \\
\text { fiber 1,5\% }\end{array}$ & 5 & $24,912 \pm(2,655)$ & \\
\hline $\begin{array}{l}\text { The mean the watersorption is different } \\
\text { between: }\end{array}$ & $0,014^{*}$ \\
$-\quad \begin{array}{l}\text { Without E-glass fiber with E-glass } \\
\text { fiber 1\% }\end{array}$ & $0,0001^{*}$ \\
Without E-glass fiber with E-glass \\
fiber 1.5\% \\
$\begin{array}{l}\text { E-glass fiber 1\% withE-glass fiber } \\
1,5 \%\end{array}$ & $0,010^{*}$ \\
\hline
\end{tabular}

\section{Effect of addition E-glass fiber to Color Stability}

ANOVA test results showed the effect of the addition of E-glass fibers in thermoplastic nylon denture base material to the color stability with value $p=0,0001(p<0,05)$. Based on LSD test results show significant difference between the nylon thermoplasticdenture base material without and with the addition of E-glass fiber $1 \%$ with $\mathrm{p}=0,012(\mathrm{p}<0,05)$ and with additional of E-glass fiber $1.5 \%$ with $\mathrm{p}=0,0001(\mathrm{p}<0,05)$. Significant differences were also found between thermoplasticnylon denture base material with the addition of E-glass fiber $1 \%$ and $1.5 \%$ with value $\mathrm{p}=0,010(\mathrm{p}<0,05)$. (Table 5)

Table 5. Effect of the addition E-glass fiber $1 \%$ and $1.5 \%$ tocolor stability of thermoplasticnylon denture base material without thermocycling

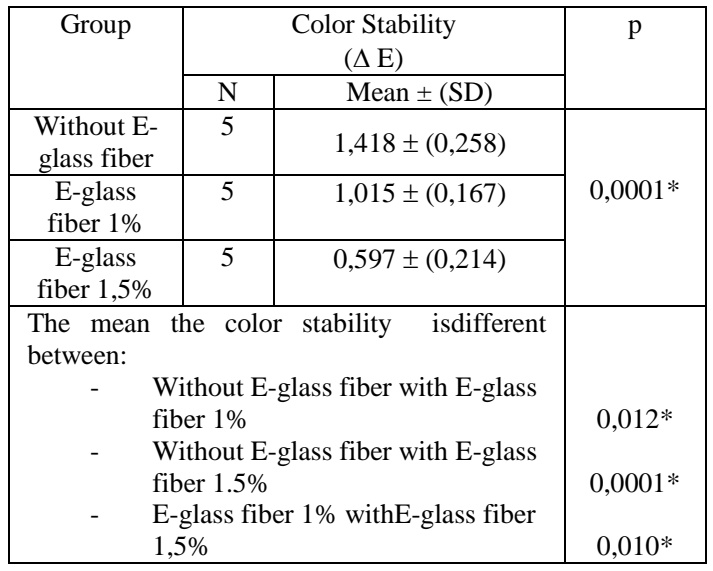

ANOVA test results showed the effect of the addition of E-glass fibers in thermoplastic nylon denture base material to the value of the color stabilitywith $\mathrm{p}=0,0001(\mathrm{p}<0,05)$. Based on LSD test results, it showeda 
significant difference between the thermoplasticnylondenture base material without and with the addition of Eglass fiber $1 \%$ with $\mathrm{p}=0,0001(\mathrm{p}<0,05)$ and with additional of E-glass fiber $1,5 \% \mathrm{p}=0,0001$. Significant differences were also found between thermoplasticnylon denture base material with the addition of E-glass fiber $1 \%$ and $1.5 \%$ with value $\mathrm{p}=0,029(\mathrm{p}<0,05)($ Table 6$)$.

Table 6.Effect of the addition E-glass fiber to color stability of the thermoplastic nylon denture base material with thermocycling

\begin{tabular}{|c|c|c|c|}
\hline \multirow[t]{2}{*}{ Group } & \multicolumn{2}{|r|}{$\begin{array}{l}\text { Color stability } \\
(\Delta \mathrm{E})\end{array}$} & \multirow[t]{2}{*}{$\mathrm{p}$} \\
\hline & $\mathrm{n}$ & Mean $\pm(\mathrm{SD})$ & \\
\hline $\begin{array}{l}\text { Without E- } \\
\text { glass fiber }\end{array}$ & 5 & $4,238 \pm(0,683)$ & \multirow{3}{*}{$0,0001 *$} \\
\hline $\begin{array}{c}\text { E-glass } \\
\text { fiber } 1 \%\end{array}$ & 5 & $2,605 \pm(0,446)$ & \\
\hline $\begin{array}{c}\text { E-glass } \\
\text { fiber } 1,5 \%\end{array}$ & 5 & $1,842 \pm(0,218)$ & \\
\hline \multicolumn{3}{|c|}{$\begin{array}{l}\text { The mean the color stability isdifferent } \\
\text { between: }\end{array}$} & \\
\hline \multicolumn{3}{|c|}{$\begin{array}{l}\text { Without E-glass fiber with E-glass } \\
\text { fiber } 1 \% \\
\text { Without E-glass fiber with E-glass } \\
\text { fiber } 1.5 \% \\
\text { E-glass fiber } 1 \% \text { withE-glass fiber } \\
1,5 \%\end{array}$} & $\begin{array}{c}0,0001 * \\
0,0001 * \\
0,029 *\end{array}$ \\
\hline
\end{tabular}

\section{Discussion}

The water sorption of thermoplastic nylon denture base material in thermocycling groupwithout and with the addition of E-glass fiber $1 \%$ and $1.5 \%$ were higher compared with those without thermocycling. This happened because hydration process occurs due to thermocycling, which was according to the clinical condition, therefore, the material absorbs water thus damaging the bonding. Water was absorbed directly damage the bond and forming a void between the layers. ${ }^{21,25}$ In thermocycling there was a change in temperature and humidity, while temperature affect the amount of water in the sorption due to coefficient diffusion increases with the temperature difference. ${ }^{17,26}$ In clinical use, denture base will be exposed to changes in temperature and saliva. In the oral cavity, moisture was contaminated and temperature variations facilitated the sorption of water. Water absorbed will react into a plasticizer and affect the properties of the material. Sorption of water will increase at a high temperature. ${ }^{27}$ Pusz A. (2011) stated that the sorption of saliva in the polyamide material which was added E-glass fiber depend on the temperature, the higher the temperature the fastersorption. ${ }^{28}$ Significantly thermocycling also affect sorption, solubility, hardness and color changes of a polymer material. ${ }^{22}$

The average value of color changes in thermoplastic nylondenture base material without E-glass fiber in thermocycling was not clinically acceptable $\Delta \mathrm{E}=4,238(\Delta \mathrm{E}>3,3)$, meaning that if the value $\Delta \mathrm{E}$ above 3.3 will be clinically obvious and unacceptable. This was probably due to large water sorption values thus causing changing of color. The results showed excessive water sorption at denture base material will cause changing of color. ${ }^{3,12,13}$ Water were absorbed through the process of diffusion will fill the spaces between the matrix resin, causing changes in the structure which will be followed by physical changes. Chandu G.S dkk. (2015) states that the samples were immersed in hot water showed significant color changes compared to the samples immersed in warm water. ${ }^{27}$ Vanessa M.F (2010) also found the difference in color between the acrylic resin before and after thermocycling after the 3000 cycle with the temperature of $5^{0}-55^{0}$ for 60 seconds. ${ }^{26}$ Nadira A.H. (2013) stated the most color changes after thermocycling were on thermoplastic nylon material than acrylic resin, with values $\Delta \mathrm{E}>3,7$ (the color changes that can not be accepted) possibly because nylon is a hydrophilic material, has a large water sorption and easy for color changes. ${ }^{23}$ This statement was also approved by Lai and Goiato which states that the color changes of thermoplasticnylon were higher than acrylic resin because nylon is hydrophilic material with a high sorption of water and a rougher surface than the acrylic resin. ${ }^{5}$ Vanessa M.F. (2010) also stated the same thing that the color changes of a material can be an indicator that the material was undergone aging or damaged, until causing major changes of characteristicsuch as water sorption and solubilization. Changes the molecular structure of the polymer due to the aging process can be caused by the breaking of the polymer chain by ultraviolet light, cross linking of oxygen, the release of plasticizer and watersorption. ${ }^{26}$

The addition of E-glass fiber affect the sorption of water in the group without and with thermocycling 2000 cycle. E-glass fiber that done with surface treatment with silane coupling agent will eliminate the water contained in the surface so that there was a more stable bond between the silane and glassfiber rather than water and glassfiber. The function of the silane coupling agent was to eliminate water sorbed and produced strong chemical bonding between the oxide group on the surface of the glass fiber and polymer molecules of the resin. 
Silane coupling agent widely used to obtain the chemical bond and the general formula $: \mathrm{R}-\mathrm{Si}-\mathrm{X}_{3}$, where $\mathrm{R}$ is an organo-functional group, unit $\mathrm{X}$ is a group that is hydrolyzed bonded with silane. $\mathrm{R}-\mathrm{Si}-\mathrm{X}_{3}$ undergo hydrolysis to produce the final result of silanol : $\mathrm{R}-\mathrm{Si}-\mathrm{X}_{3}+3 \mathrm{H}_{2} \mathrm{O} \rightarrow \mathrm{R}-\mathrm{Si}(\mathrm{OH})_{3}+3 \mathrm{HX}$. Trihydroxy-silanols can eliminate the water on the surface of fiberglass by forming hydrogen bonds with hydroxyl groups on the surface of the glass fiber. When glassfiber coated by silane, it underwent dryness, water was removed and condensation reactions occur between the silanol and surface. When bonding occurred, the hydrolysis reaction can not occur again. This would produced bonding and strong water resistance.Vurakkara VR (2006) stated that the reinforcement fibers can significantly reduce water sorption. ${ }^{18}$ AL-Habahbeh (2007) also stated E-glass fiber is added to the acrylic resin showed a significant decrease in water sorption due to the hydrophobic fiber so it can anticipate the characteristic of the hydrophilic acrylic resin. ${ }^{29}$ The amount of water adsorbed by the resinbased material depends to resin content and quality of the bond between resin as the matrix polymer and glass fiber as filler. ${ }^{30}$ The concentration of glassfiber is added to the acrylic resin can affect the rate of water sorption of a polymer material. The higher the concentration of glassfiber was used, the lower the value ofwater sorption. $3,16,31$

The addition of E-glass fiber $1 \%$ and $1.5 \%$ effect on color stability of the thermoplastic nylondenture base material without and with thermocycling 2000 cycles, it is probably because the value of water sorption in denture base material was reduced by the addition of E-glass fiber so that the stability of the color to be increased. Previously, the results of some studies showed excessivesorption of water on denture base material will cause color change. $3,12,13$

\section{Conclusion}

Thermocycling 2000 cycle was for simulated oral conditions during the 2 years of use denture to show the effect on water sorption and color stability. E-glass fiber was added to the denture base materials also affect the sorption of water and color stability. Color changes of thermoplasticnylon denture base material caused by thermocycling was not seen visually and can be acceptable when added E-glass fiber $1 \%$ to $1.5 \%(\Delta \mathrm{E}<3,3)$, when if it was not added E-glass fiber the color changes seen visually and unacceptable $(\Delta \mathrm{E}>3,3)$.

\section{References}

[1]. Mc.Cracken's., Removable Partial Prosthodontics. Edisi 10. CV. Mosby Company. $2000: 127$.

[2]. McCabe JF., Walls AWG. Applied dental materials. Edisi 9. London: Blackwell Munksgaard.2007: 110-23.

[3]. Kortrakulkij K. Effect of denture cleanser on color stability and flexural strength of denture base materials. Thesis. Mahidol, Thailand: Mahidol University. 2008: 4-18.

[4]. Chhnoeum T. Effect of denture cleanser on the surface roughness and hardness of denture base material. Thesis.Mahidol University. $2008: 8-15$.

[5]. Elshereski NW., 2006. Mechanical and environmental properties of denture base poly(methyl meracrylate) filled by barium titanate. Thesis: $13-4,24$

[6]. Negrutiu M., Sinescu C., Romanu M., dkk., Thermoplastic resins for flexible framework removable partial dentures. (15 Agustus 2010). http://www.tmj.ro/pdf/2005_number_3_833235561124423.pdf .

[7]. Manappallil JJ. Basic Dental Materials. Edisi 2. Jaypee Brothers:New Delhi. 2003: 99-118.

[8]. Prashanti E., Jain N., Shenoy VK.,. Flexible dentures : A flexible option to treat edentulous patients. Journal of Nepal association. $2010 ; 11(1): 85-7$.

[9]. Pusz A., Szymiczek M., Michalik K. Ageing process influence on mechanical properties of polyamide-glass composites applied in dentistry. Journal of Achievements in Materials and Manufacturing Engineering. $2010 ; 38(1)$ : 49-55.

[10]. Kamath S. Comparison of mechanichal properties of high impact polymethylmethacrylate resin an co-polyamide nylon resin used for denture base construction. Dissertation.Departement of prosthodontics. Government dental college and hospital.Bangalore .2006: 1-52.

[11]. Takabayashi Y., 2010. Characteristics of denture thermoplastics resins for non-metal clasps dentures. Dental materials journal ; 29(4): 353-61.

[12]. Goiato MC., Santtos DM., Haddad MF., Pesquiera AA. Effect of accelerated aging on the microhardness and colour stability of flexible resins for dentures. Journal of Braz oral res. 2010.24(1): 114-9.

[13]. Saied HM., 2011. Influence of dental cleansers on the color stability and surface roughness of three types of denture bases. J Bagh college dentistry ; 23(3): 17-22.

[14]. Celik C., Yuzugullu B., Erkut S., Yamanel K., 2008. Effects of mouth rinses on colorstability of resin composites. Eur J dent; 2: 247-253.

[15]. Assuncao WG., Barao VAR., Pita MS., Goiato MC. Effect of polymerization methods and thermal cycling on color stability of acrylic resin denture teeth. J Prosthet Dent. 2009;102;385-92.

[16]. Pollat TN., Valitu P. Water sorption, solubility and dimensional changes of denture base polymers reinforced with short glass fibers. Journal of biomater appl. $2003 ; 17: 321-35$.

[17]. Powers JM., Sakaguchi RL. Craig's Restorative dental materials. Ed-12.Mosby Elsevier, St. Louis. Missouri. 2006 : 514 - 36.

[18]. Vurakkara VR., 2006. An in-vitro study to evaluate the effect of thickness of different heat cured acrylic denture base materials on water sorption, linear dimensional change and warpage.Dissertation. K.L.E Society's institute of dental science. Belgaum, Karnataka. : 1-56.

[19]. Lee SI., Kim CW., Kim YS. Effect of chopped glass fiber on the strength of heat-cured PMMA resin. J Korean Acad Prosthodont. 2001; 39(6): 590-6.

[20]. Ariyani. Pengaruh penambahan fiber glass reinforced terhadap penyerapan air dan stabilitas warna bahan basis nilon termoplastik. Tesis. Program studi magister (S2) ilmu kedokteran gigi, Fakultas Kedokteran Gigi Universitas Sumatera Utara. 2013 : 75-98. 


\section{Effect of Thermocycling And E-Glass Fiber Addition On Water Sorption And Color Stability of ...}

[21]. GoiatoMC., Zucolotti BCR., Santos DM. Effects of thermocycling on mechanical properties of soft lining materials. Acta Odontol. Latinoam.2009;2(3): 227-32.

[22]. Mancuso DN., Goiato MC., Zucolotti BCR., Moreno A. Effect of thermocycling on hardness, absorption, solubility and colour change of soft liners. Gerrodontology. 2012; 29: 215-9.

[23]. Nadira AH., Omar ZA. Comparative evaluation of color change between two types of acrylic resin and flexible resin after thermocycling: An In Vitro study. J Indian Prosthodont Soc.2013;13(3):327-37.

[24]. International Standart., 1988. The International organization for standardization . ISO $4049: 12-5$.

[25]. Lekha K., Savitha NP., Roseline M., Nadiger RK. Acetal resin as an aesthetic clasp material. Journal of Interdisciplinary Dentistry. 2012;2(1): 11-4.

[26]. Vanessa MF., Marina X., Helena FO., Raphael FS., Claudia HS. Effect of ageing and immersion in different beverages on properties of denture lining materials. J Appl Oral Sci. 2010;18(4):372-8.

[27]. Chandu GS., Asnani P., Gupta S., Khan MF. 2015. Comaparative evaluation of effect of water absorption on the surface properties of heat cure acrylic: An in vitro study. Journal of international oral health.;7(4): 1-6.

[28]. Pusz A., Szymiczek M., Michalik K.Topography and the surface of polyamide -glass composites after the ageing process. Journal of achievements in materials and manufacturing engineering. 2011;44(1):42-9.

[29]. AL-Habahbeh R. Water absorption and solubility of provisional crown andbridge: The effect of the inclusion of polyethylene fibers. JRMS 2007.; 14(1):22-5.

[30]. Noort R., 2007. Introduction to dental materials. Edisi $3:$ 216-22. London: Mosby Elsevier.

[31]. Gurbuz O., Unalan F., Kursoglu P., 2005. Water resorption and solubility of denture teeth acrylic resin reinforced with milled glass fiber. OHDMBSC; IV . 4: 57-62. 